\title{
ПРОИЗВОДНЫЕ ТЕРПЕНОИДОВ - ОСНОВА ПРОТИВОВИРУСНЫХ АГЕНТОВ ДЛЯ ЛЕЧЕНИЯ И ПРОФИЛАКТИКИ ВИРУСНЫХ ИНФЕКЦИЙ, В ТОМ ЧИСЛЕ КОРОНАВИРУСА
}

\author{
И.Ю. Чукичева', И.А. Дворникова', С.А. Попова', В.В. Зарубаев², \\ А.В. Кучин ${ }^{1}$ \\ ${ }^{1}$ Институт химии Коми научного центра Уральского отделения Российской академии \\ наук, 167000, Россия, Сыктывкар, ул. Первомайская, 48. \\ 2ФБУН НИИ эпидемиологии и микробиологии имени Пастера \\ 197101, Россия, Санкт-Петербург, ул. Мира, 14.
}

DOI: 10.19163/MedChemRussia2021-2021-324

E-mail: chukichevaiy@mail.ru

Одним из современных инновационных подходов в области разработки новых противовирусных препаратов является поиск противовирусных агентов широкого спектра действия среди природных соединений, выделяемых из доступного растительного сырья и их производных.

Целью настоящего исследования являлось выявление соединений лидеров по противовирусной активности in vitro в ряду синтезированных производных монотерпеноидов.

Синтезированы библиотеки новых производных терпенофенолов с различным строением терпенового фрагмента; серии гидроксикумаринов, отличающихся числом, расположением и строением терпенового заместителя и отличающихся расположением гидроксильных групп; диамины с разной структурой терпенового заместителя и линкера между атомами азота.

Цитотоксические и противовирусные свойства производных терпеноидов изучались в культуре клеток MDCК в отношении вируса гриппа A/Puerto Rico/8/34 9H1N1). Противовирусный потенциал соединений-лидеров был далее оценен в отношении других респираторных вирусов человека - коронавируса OC43, аденовируса человека 5 типа и вируса парагриппа человека 3 типа. Экспериментально было установлено, что вирусингибирующая активность соединений-лидеров проявлялась в отношении респираторных вирусов человека в меньшей степени, чем в отношении вируса гриппа. При этом оболочечные вирусы (коронавирус и вирус парагриппа) оказались более чувствительны к действию терпеновых соединений, чем безоболочечный аденовирус.

Работа выполнена при финансовой поддержке РФФИ

(научный проект № 20-04-60493). 